Journal of Agricultural Sciences
(Tarim Bilimleri Dergisi)

\title{
Investigation of Alkaloids in Opium Poppy (Papaver somniferum L.) Varieties and Hybrids
}

\author{
Levent YAZiCía ${ }^{(D)}$, Güngör YILMAZ ${ }^{\text {iD }}$

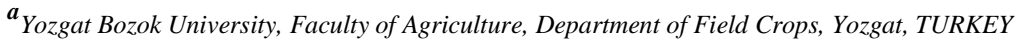

\section{ARTICLE INFO} \\ Research Article \\ Corresponding Author: Levent YAZİĊ, E-mail: leventyzc@gmail.com \\ Received: 28 August 2019 / Revised / 27 September 2019 / Accepted: 24 October 2019 / Online: 18 January 2021
}

\section{ABSTRACT}

This study aimed to investigate the proportions of morphine, thebaine, noscapine, codeine, oripavine and papaverine alkaloids in poppy varieties and hybrids. Nine parents and 36 hybrid lines were used in the trial. The trial was carried out in 2016 and 2017 in four replications according to the Randomized Block Trial Design. According to the average results of the two years, in parent and hybrid combinations, morphine was found to vary between $0.42 \%$ and $1.66 \%$, thebaine between $0.01 \%$ and $0.53 \%$, noscapine between $0.01 \%$ and $0.31 \%$, codeine between $0.03 \%$ and $0.17 \%$, oripavine between $0.00 \%$ and $0.12 \%$ and papaverine between $0.00 \%$ and $0.10 \%$. In the study, Ofis NM $\mathrm{x}$ Ofis 1 , Ofis $1 \mathrm{x}$ TMO T, Ofis $2 \mathrm{x}$ TMO T, Ofis NM x Ofis 1, Ofis NM $\mathrm{x}$ TMO $\mathrm{T}$ hybrid combinations were identified as superior hybrids compared to the others.

Keywords: Alkaloids; Diallel hybridization; Morphine; Poppy; Papaver somniferum L.

(C) Ankara University, Faculty of Agriculture

\section{Introduction}

Papaver somniferum L. species $(2 \mathrm{n}=22)$ the opium poppy, is a traditionally cultivated annual cultivar. It is grown in Turkey, India, Australia, Spain, France and Hungary as legal main producer countries under the supervision of the United Nations to obtain opium and opium alkaloids for medicinal purposes in World (TMO 2014). India produces opium gum, whereas other countries produce dried opium capsules. The average legal opium poppy cultivation area in 2014-2020 is 79 thousand ha on the basis of main producers in the World, the average morphine equivalent raw material production was 483 tons (INCB 2020). Average most poppy cultivation has been realized with share of 52\% in Turkey and with a share of $15 \%$ in Australia.

Poppy cultivation for a long time in Anatolia geography, including Sumerians and many civilizations since dates back to $4000 \mathrm{BC}$ and it used for various purposes (Tan 2008). There are 7 species of poppy family in Turkey. Studies report that there is a total of 58 papaver taxa including 36 species and 22 subspecies and varieties, 15 of which are endemic (Guner et al. 2012).

Opium poppy makes a significant contribution to the country economy in terms of making up both morphine and derivatives export. In Afyon Alkaloids Factory with its 25.000 tons/year dried un-incised poppy capsule processing capacity, which was established to commercialize opium poppy and meet the legal alkaloid requirement of the market, approximately 80-100 tons of morphine is produced annually based on the proportion of morphine in capsules. Morphine and its derivatives are used in domestic pharmaceutical industry and the rest $95 \%$ is exported for medical purposes (TMO 2017).

Opium poppy (Papaver somniferum L.) plant has two important products in terms of use. One of the products is capsules and the alkaloids in them, and the other is seeds and oil. Researchers have identified 80 different alkaloids of medical importance in opium poppy capsules, from which a large number of important alkaloids are obtained (Celik 2011; Mishra et al. 2013; Marciano et al. 2018). A large number of alkaloids are obtained from opium poppy (Papaver somniferum L.), and morphine, codeine, thebaine, noscapine, oripavine, and papaverine are among the most important ones. These alkaloids are used as active ingredients of many drugs. Yazici et al. (2017) the alkaloid contents of some poppy varieties and genotypes reported that the rate of morphine varied from $0.53 \%$ to $0.58 \%$, the codeine $0.02 \%$ to $0.08 \%$, the oripavine $0.0005 \%$ to $0.005 \%$, the thebaine $0.006 \%$ to $0.02 \%$, the noscapine $0.02 \%$ to $0.19 \%$ and papaverine $0.01 \%$ to $0.09 \%$ in the varieties. In the genotypes was reported the rate of morphine varied between $0.15 \%$ and $0.60 \%$, the codeine $0.001 \%$ to $0.21 \%$, the oripavine $0.00 \%$ to $0.01 \%$, the thebaine $0.001 \%$ to $0.08 \%$, the noscapine $0.005 \%$ to $0.20 \%$, and the papaverine $0.004 \%$ to $0.21 \%$. Morphine is the most important alkaloid that is found in the maximum amount in the poppy capsule. Arslan et al. (2000) 
morphine proportions were found between $0.25 \%$ and $0.89 \%$ in 353 samples collected from various regions. Kara (2017) stated that the morphine content of fifteen poppy cultivars varied between $0.47 \%$ and $1.00 \%$ in the autumn sowing and between $0.45 \%$ and $0.97 \%$ in the spring sowing, respectively. Morphine is a strong analgesic (pain killer), utilized to relieve severe pains and to prepare the patient for surgery. Codeine is a very good antitussive (cough controller) as it eliminates the cough response. Thebaine is the most poisonous opium alkaloid. It is not used as a drug; it has a stimulant effect on the central nervous system. Noscapine is the second most common alkaloid after morphine in opium, and it is cough sedative. Papaverine has a pronounced antispasmodic effect on striated and especially non-striated muscles. Oripavine, on the other hand, is used in the treatment of cocaine addiction (Tanker \& Tanker 1990; Baser \& Arslan 2014; Inal 2015; UNODC 2018). This study aimed at examining the proportions of morphine, thebaine, noscapine, codeine, oripavine, and papaverine alkaloids in opium poppy varieties and hybrids.

\section{Material and Methods}

In the study, nine different opium poppy varieties (Ofis 96, TMO 1, Huseyinbey, Celikoglu, Ofis NM, Ofis 1, Bolvadin 95, Ofis 2, and TMO T) were used for half diallel crosses (Table 1). The genetic material of the study consisted of nine parents and 36 hybrids obtained through half diallel hybridization method [n. (n-1)/2]. Nine opium poppy cultivars used as parents were sown in the trial field of the Directorate of Middle Black Sea Transition Zone Agricultural Research Institute under TokatKazova conditions on 27 February 2015 to obtain the hybrid seeds to be used as the study material. The varieties used in the trial were planted as three replications in two rows of $3 \mathrm{~m}$ length and $45 \mathrm{~cm}$ row spacing. $10 \mathrm{~cm}$ plant spacing was obtained with later thinning, and $1 \mathrm{~m}$ space was left between varieties for the ease of performing hybridization and inbreeding operations. To ensure that the blooming dates of the varieties to be used as fathers and mothers coincide, all varieties were sown again in two rows one month later. F1 hybrid seeds obtained through hybridization and inbred parents were divided into two groups, and they were sown in the trial field of the Directorate of Agricultural Research Institute in 2015-2016 and 20162017 vegetation periods in four replications according to the randomized block trial design. The experiment was carried out in two rows of $3 \mathrm{~m}$ length and $45 \mathrm{~cm}$ row spacing, and $10 \mathrm{~cm}$ plant spacing with later thinning. In the study, adequate amount of samples were extracted from capsule shells of each combination, they were ground to powder, and then their alkaloid (morphine, thebaine, noscapine, codeine, oripavine and papaverine) ratios were determined using HPLC analysis method (Kucuk 1996).

Table 1- Parents used in the trial and 9x9 half diallel hybridization combinations

\begin{tabular}{|c|c|c|c|}
\hline \multicolumn{4}{|c|}{ Parents } \\
\hline Item No & & Item $\mathrm{No}$ & \\
\hline 1 & Ofis 96 & 6 & Ofis 1 \\
\hline 2 & TMO 1 & 7 & Bolvadin 95 \\
\hline 3 & Huseyinbey & 8 & Ofis 2 \\
\hline 4 & Celikoglu & 9 & TMO T \\
\hline 5 & Ofis NM & & \\
\hline \multicolumn{4}{|c|}{ Hybridization combinations } \\
\hline $1 \times 2$ & Ofis 96 x TMO 1 & $3 \times 7$ & Huseyinbey x Bolvadin 95 \\
\hline $1 \times 3$ & Ofis 96 x Huseyinbey & $3 \times 8$ & Huseyinbey x Ofis 2 \\
\hline $1 \times 4$ & Ofis 96 x Celikoglu & $3 \times 9$ & Huseyinbey x TMO T \\
\hline $1 \times 5$ & Ofis 96 x Ofis NM & $4 \times 5$ & Celikoglu x Ofis NM \\
\hline $1 \times 6$ & Ofis 96 x Ofis 1 & $4 \times 6$ & Celikoglu x Ofis 1 \\
\hline $1 \times 7$ & Ofis $96 \times$ Bolvadin 95 & $4 \times 7$ & Celikoglu x Bolvadin 95 \\
\hline $1 \times 8$ & Ofis 96 x Ofis 2 & $4 \times 8$ & Celikoglu x Ofis 2 \\
\hline $1 \times 9$ & Ofis 96 x TMO T & $4 \times 9$ & Celikoglu x TMO T \\
\hline $2 \times 3$ & TMO 1 x Huseyinbey & $5 \times 6$ & Ofis NM x Ofis 1 \\
\hline $2 \times 4$ & TMO 1 x Celikoglu & $5 \times 7$ & Ofis NM x Bolvadin 95 \\
\hline $2 \times 5$ & TMO 1 x Ofis NM & $5 \times 8$ & Ofis NM x Ofis 2 \\
\hline $2 \times 6$ & TMO 1 x Ofis 1 & $5 \times 9$ & Ofis NM x TMO T \\
\hline $2 \times 7$ & TMO 1 x Bolvadin 95 & $6 \times 7$ & Ofis $1 \times$ Bolvadin 95 \\
\hline $2 \times 8$ & TMO 1 x Ofis 2 & $6 \times 8$ & Ofis $1 \times$ Ofis 2 \\
\hline $2 \times 9$ & TMO 1 x TMO T & $6 \times 9$ & Ofis $1 \mathrm{x}$ TMO T \\
\hline $3 \times 4$ & Huseyinbey x Celikoglu & $7 \times 8$ & Bolvadin 95 x Ofis 2 \\
\hline $3 \times 5$ & Huseyinbey x Ofis NM & $7 \times 9$ & Bolvadin $95 \times$ TMO T \\
\hline $3 \times 6$ & Huseyinbey x Ofis1 & $8 \times 9$ & Ofis 2 x TMO T \\
\hline
\end{tabular}

\section{Results and Discussion}

Genetic diversity is important in plant breeding. Presence of genetic variability is the basic requirement for developing high alkaloid content and better yield varieties in opium poppy. The results of the variance analysis showed that were significant $(\mathrm{P} \leq 0.01)$ differences among the parents and their $\mathrm{F} 1$ progenies in traits studied except for noscapine in the first year (Table 2). 
Table 2- Mean squares of variance analysis regarding alkaloid ratios of F1 hybrid combinations and their parents

\begin{tabular}{lcllllll}
\hline $\begin{array}{l}\text { Variation } \\
\text { Sources }\end{array}$ & DF & Morphine & Thebaine & Noscapine & Codeine & Oripavine & Papaverine \\
\hline Repeats & 3 & 0.018 & $0.018^{* *}$ & $0.009^{* *}$ & $0.007^{* *}$ & 0.0001 & 0.0005 \\
Genotypes & 44 & $0.288^{* *}$ & $0.034^{* *}$ & 0.002 & $0.002^{* *}$ & $0.0007^{* *}$ & $0.0014^{* *}$ \\
Error & 132 & 0.033 & 0.003 & 0.002 & 0.0006 & 0.0000 & 0.0004 \\
CV $(\%)$ & & 23.97 & 64.81 & 98.98 & 42.65 & 110.78 & 117.7 \\
\hline $\begin{array}{l}\text { Variation } \\
\text { Sources }\end{array}$ & DF & Morphine & Thebaine & Noscapine & Codeine & Oripavine & Papaverine \\
\hline Repeats & 3 & 0.120 & $0.034^{*}$ & 0.010 & 0.005 & 0.0008 & 0.002 \\
Genotypes & 44 & $0.832^{* *}$ & $0.092^{* *}$ & $0.086^{* *}$ & $0.007 * *$ & $0.0048^{* *}$ & $0.004 * *$ \\
Error & 132 & 0.050 & 0.011 & 0.010 & 0.003 & 0.0010 & 0.002 \\
CV $(\%)$ & & 20.66 & 82.44 & 52.57 & 60.43 & 206.66 & 157.14 \\
\hline
\end{tabular}

*, **; Significant at $\mathrm{P}<0.05$ and $\mathrm{P}<0.01$ probability levels, respectively

\subsection{Morphine ratio}

The morphine ratio in the parents was found to vary between $0.35 \%$ and $1.30 \%$ in the first year, and it was determined to be $0.67 \%$ on average. In the second year, the ratio was determined between $0.40 \%$ and $1.85 \%$, and the average was $0.92 \%$. According to the average results of two years, the highest morphine ratio in the parents was found in Ofis 2 and Ofis 1 cultivars, while the lowest proportions were in Bolvadin 95 and Huseyinbey cultivars. The proportion of morphine in F1 hybrid combinations ranged between $0.42 \%$ and $1.40 \%$ in the first year with average of $0.78 \%$, while it was between $0.46 \%$ and $2.03 \%$, and with average of $1.12 \%$ in the second year. The highest morphine ratio in hybrid combinations was determined in Ofis NM x Ofis 1 and Ofis 1 x TMO T hybrids, whereas the lowest ratios were in Ofis 96 x Huseyinbey and TMO 1 x Huseyinbey hybrid combinations (Table 3 and 4). Harvest et al. (2009) demonstrated that morphine content correlated with capsule mass and total latex mass. Yadav et al. (2007) stated that positive correlations were determined between the morphine content with the size of the capsule and their weight. Thus, in hybrid combinations, varieties for both high capsule yield and morphine content can be developed. Dubedout (1993) reported that no correlation between the agromorphological characteristics and the content of the morphine. Moreover, the morphine content is often average between the parents values in hybrids. According to the work of Khanna \& Shukla (1989) maternal effects had observed for earliness, seed weight, morphine content, plant height, flowering period and number of capsules. Danos (1968) who reported that the quantity of morphine alkaloids in the capsule increases under hot and dry cultivation conditions, while rainy weather after flowering and seed setting reduces the alkaloid content. In this study, it was thought that the precipitation in the first year was higher than the second year and it had a negative effect on the decrease in morphine content. According to the average findings of the two years, morphine content of F1 hybrid combinations $(0.95 \%)$ was higher than either of the parents $(0.80 \%)$. Hybrid combinations are higher than their parents shows that has an effect of hybrid vigour.

\subsection{Thebaine ratio}

The proportion of thebaine in the parents was found to range between $0.01 \%$ and $0.42 \%$ and the average was determined as $0.09 \%$ in the first year, the ratio varied between $0.00 \%$ and $0.63 \%$ and the average ratio was $0.12 \%$ in the second year. The highest thebaine ratio in parents was found in TMO T, while the lowest was in TMO 1 varieties. The rate of thebaine in F1 hybrid combinations was determined as $0.02-0.37 \%$, and average was $0.09 \%$ in the first year. In the second year, was determined between 0.00 and $0.61 \%$, and with average of $0.13 \%$. The highest ratio of thebaine in hybrids was in Ofis $2 \mathrm{x}$ TMO $\mathrm{T}$, and the lowest was in TMO 1 x Huseyinbey hybrid combinations (Table 3 and 4). Dubedout (1993) reported that morphine content was positively correlated to the thebaine and codeine contents. Selection would be effective to improve these traits simultaneously. No relation was found between the thebaine content and yield in capsules. The highest thebaine was obtained at the start of flowering (Levy et al. 1986; Levy et al. 1988). Saco \& Lopez-Belmonte (1988) was found significant negative correlation between precipitation $(\mathrm{mm})$ and thebaine content.

\subsection{Noscapine ratio}

The proportion of noscapine in the parents was found to vary between $0.00 \%$ and $0.09 \%$, and average was $0.04 \%$ in the first year, In the second year, the ratio was determined between $0.02 \%$ and $0.53 \%$ and $0.16 \%$ on average. The highest and the 
lowest noscapine ratios in parents were found in Ofis 96 and Celikoglu, respectively. The rate of noscapine in F1 hybrid combinations ranged between 0.01 and $0.12 \%$ in the first year, and average was $0.05 \%$. In the second year, ranged between 0.05 and $0.58 \%$, and the average was $0.20 \%$. The highest ratio of noscapine in hybrid combinations was found in Ofis NM $\mathrm{x}$ Ofis 1, Ofis 1 x TMO T, while the lowest was determined in Ofis 96 x Celikoglu and TMO 1 x Celikoglu hybrid combinations (Table 3 and 4). Ozgen et al. (2017) in a study reported that noscapine ratio ranged between $0.00 \%$ and $1.79 \%$ in experiment using 22 lines and one standard variety.

Table 3- Mean values of 2016 and 2017 related to the proportion of alkaloids in the parent (\%)

\begin{tabular}{|c|c|c|c|c|c|c|c|c|c|}
\hline \multirow[t]{2}{*}{ *Parents } & \multicolumn{3}{|c|}{ Morphine (\%) } & \multicolumn{3}{|c|}{ Thebaine (\%) } & \multicolumn{3}{|c|}{ Noscapine (\%) } \\
\hline & 2016 & 2017 & Mean & 2016 & 2017 & Mean & 2016 & 2017 & Mean \\
\hline (1) & 0.39 & 0.52 & 0.45 & 0.03 & 0.20 & 0.11 & 0.03 & 0.53 & 0.28 \\
\hline (2) & 0.49 & 0.62 & 0.55 & 0.02 & 0.00 & 0.01 & 0.04 & 0.07 & 0.05 \\
\hline (3) & 0.46 & 0.40 & 0.43 & 0.06 & 0.07 & 0.06 & 0.07 & 0.09 & 0.08 \\
\hline (4) & 0.49 & 0.69 & 0.59 & 0.04 & 0.05 & 0.04 & 0.00 & 0.02 & 0.01 \\
\hline (5) & 0.82 & 0.95 & 0.88 & 0.08 & 0.05 & 0.06 & 0.09 & 0.11 & 0.10 \\
\hline (6) & 1.30 & 1.85 & 1.57 & 0.10 & 0.02 & 0.06 & 0.04 & 0.22 & 0.13 \\
\hline (7) & 0.35 & 0.49 & 0.42 & 0.01 & 0.05 & 0.03 & 0.06 & 0.14 & 0.10 \\
\hline (8) & 0.92 & 1.72 & 1.32 & 0.05 & 0.03 & 0.04 & 0.03 & 0.08 & 0.05 \\
\hline (9) & 0.84 & 1.07 & 0.95 & 0.42 & 0.63 & 0.52 & 0.08 & 0.24 & 0.16 \\
\hline Mean & 0.67 & 0.92 & 0.80 & 0.09 & 0.12 & 0.10 & 0.04 & 0.16 & 0.10 \\
\hline SE & 0.05 & 0.09 & & 0.02 & 0.03 & & 0.008 & 0.02 & \\
\hline \multirow[t]{3}{*}{ Range $\%$} & $0.28-1.53$ & \multicolumn{2}{|c|}{$0.26-2.23$} & $0-0.58$ & \multicolumn{2}{|r|}{$0-0.85$} & $0-0$. & \multicolumn{2}{|r|}{$0-0.71$} \\
\hline & \multicolumn{3}{|c|}{ Codeine (\%) } & \multicolumn{3}{|c|}{ Oripavine (\%) } & \multicolumn{3}{|c|}{ Papaverine (\%) } \\
\hline & 2016 & 2017 & Mean & 2016 & 2017 & Mean & 2016 & 2017 & Mean \\
\hline (1) & 0.04 & 0.12 & 0.08 & 0.003 & 0.000 & 0.001 & 0.01 & 0.02 & 0.01 \\
\hline (2) & 0.04 & 0.05 & 0.04 & 0.001 & 0.078 & 0.039 & 0.01 & 0.00 & 0.00 \\
\hline (3) & 0.04 & 0.05 & 0.04 & 0.002 & 0.055 & 0.028 & 0.02 & 0.03 & 0.02 \\
\hline (4) & 0.05 & 0.08 & 0.06 & 0.004 & 0.000 & 0.002 & 0.00 & 0.00 & 0.00 \\
\hline (5) & 0.08 & 0.10 & 0.09 & 0.009 & 0.000 & 0.004 & 0.03 & 0.08 & 0.05 \\
\hline (6) & 0.10 & 0.00 & 0.05 & 0.004 & 0.000 & 0.002 & 0.02 & 0.00 & 0.01 \\
\hline (7) & 0.03 & 0.08 & 0.05 & 0.001 & 0.019 & 0.010 & 0.04 & 0.03 & 0.03 \\
\hline (8) & 0.07 & 0.04 & 0.05 & 0.001 & 0.000 & 0.000 & 0.01 & 0.00 & 0.00 \\
\hline (9) & 0.09 & 0.10 & 0.09 & 0.073 & 0.178 & 0.125 & 0.01 & 0.05 & 0.03 \\
\hline Mean & 0.06 & 0.06 & 0.06 & 0.010 & 0.036 & 0.023 & 0.01 & 0.02 & 0.02 \\
\hline SE & 0.005 & 0.01 & & 0.003 & 0.01 & & 0.004 & 0.008 & \\
\hline Range $\%$ & $0-0.15$ & & 0.21 & $0-0.08$ & & $0-0.35$ & $0-0$. & & $0-0.26$ \\
\hline
\end{tabular}

*(1); Ofis 96, (2); TMO 1, (3); Huseyinbey, (4); Celikoglu, (5); Ofis NM, (6); Ofis 1, (7); Bolvadin 95, (8); Ofis 2, (9); TMO T, SE; Standard error

\subsection{Codeine ratio}

Codeine ratio was determined between $0.03 \%$ and $0.10 \%$ in the first year, $0.06 \%$ on average, between $0.00 \%$ and $0.12 \%$ in the second year, and $0.06 \%$ on average in the parents. The highest codeine ratio in parents was found in TMO T, and the lowest was in TMO 1 and Huseyinbey varieties. F1 hybrid combinations, codeine ratio ranged between 0.02 and $0.14 \%$, and $0.06 \%$ on average in the first year, In the second year ranged between 0.01 and $0.21 \%$, and $0.10 \%$ on average. The highest codeine proportion in hybrids was found in Ofis 1 x TMO T and Celikoglu x Ofis 1 hybrids, while the lowest was in Huseyinbey x Ofis 2 hybrid combinations (Table 3 and 5). Papaver bracteatum L. can be used to be a potential alternative for the higher yields of 
codeine from unit area in breeding (Bohm 1981). Laughlin (1980) the highest codeine and morphine was obtained about five weeks after full flowers.

Table 4- Mean values of 2016 and 2017 for morphine, thebaine and noscapine ratios in F1 hybrid combinations (\%)

\begin{tabular}{|c|c|c|c|c|c|c|c|c|c|}
\hline \multirow[t]{2}{*}{ *Crosses } & \multicolumn{3}{|c|}{ Morphine (\%) } & \multicolumn{3}{|c|}{ Thebaine (\%) } & \multicolumn{3}{|c|}{ Noscapine (\%) } \\
\hline & 2016 & 2017 & Mean & 2016 & 2017 & Mean & 2016 & 2017 & Mean \\
\hline $1 \times 2$ & 0.47 & 0.76 & 0.61 & 0.03 & 0.01 & 0.02 & 0.04 & 0.11 & 0.07 \\
\hline $1 \times 3$ & 0.44 & 0.46 & 0.45 & 0.04 & 0.01 & 0.02 & 0.04 & 0.08 & 0.06 \\
\hline $1 \times 4$ & 0.58 & 0.53 & 0.55 & 0.03 & 0.01 & 0.02 & 0.04 & 0.05 & 0.04 \\
\hline $1 \times 5$ & 0.66 & 0.85 & 0.75 & 0.09 & 0.19 & 0.14 & 0.03 & 0.13 & 0.08 \\
\hline $1 \times 6$ & 1.02 & 1.41 & 1.21 & 0.08 & 0.16 & 0.12 & 0.08 & 0.45 & 0.26 \\
\hline $1 \times 7$ & 0.53 & 0.56 & 0.54 & 0.05 & 0.04 & 0.04 & 0.04 & 0.08 & 0.06 \\
\hline $1 \times 8$ & 0.66 & 1.04 & 0.85 & 0.03 & 0.02 & 0.02 & 0.01 & 0.12 & 0.06 \\
\hline $1 \times 9$ & 0.67 & 0.99 & 0.83 & 0.11 & 0.26 & 0.18 & 0.04 & 0.15 & 0.09 \\
\hline $2 \times 3$ & 0.42 & 0.63 & 0.52 & 0.02 & 0.00 & 0.01 & 0.04 & 0.05 & 0.04 \\
\hline $2 \times 4$ & 0.51 & 0.70 & 0.60 & 0.05 & 0.03 & 0.04 & 0.02 & 0.06 & 0.04 \\
\hline $2 \times 5$ & 0.66 & 0.95 & 0.80 & 0.03 & 0.07 & 0.05 & 0.01 & 0.11 & 0.06 \\
\hline $2 \times 6$ & 1.04 & 1.64 & 1.34 & 0.02 & 0.07 & 0.04 & 0.05 & 0.34 & 0.19 \\
\hline $2 \times 7$ & 0.63 & 0.95 & 0.79 & 0.02 & 0.08 & 0.05 & 0.08 & 0.14 & 0.11 \\
\hline $2 \times 8$ & 0.84 & 1.48 & 1.16 & 0.02 & 0.11 & 0.06 & 0.03 & 0.24 & 0.13 \\
\hline $2 \times 9$ & 0.84 & 1.08 & 0.96 & 0.05 & 0.09 & 0.07 & 0.03 & 0.20 & 0.11 \\
\hline $3 \times 4$ & 0.44 & 0.64 & 0.54 & 0.04 & 0.09 & 0.06 & 0.03 & 0.11 & 0.07 \\
\hline $3 \times 5$ & 0.60 & 0.84 & 0.72 & 0.08 & 0.19 & 0.13 & 0.03 & 0.14 & 0.08 \\
\hline $3 \times 6$ & 1.00 & 1.26 & 1.13 & 0.06 & 0.18 & 0.12 & 0.07 & 0.39 & 0.23 \\
\hline $3 \times 7$ & 0.50 & 0.59 & 0.54 & 0.04 & 0.08 & 0.06 & 0.04 & 0.09 & 0.06 \\
\hline $3 \times 8$ & 0.83 & 1.03 & 0.93 & 0.03 & 0.02 & 0.02 & 0.04 & 0.10 & 0.07 \\
\hline $3 \times 9$ & 0.93 & 0.90 & 0.91 & 0.14 & 0.25 & 0.19 & 0.04 & 0.30 & 0.17 \\
\hline $4 \times 5$ & 0.62 & 0.96 & 0.79 & 0.15 & 0.07 & 0.11 & 0.03 & 0.12 & 0.07 \\
\hline $4 \times 6$ & 1.19 & 1.52 & 1.35 & 0.12 & 0.25 & 0.18 & 0.03 & 0.32 & 0.17 \\
\hline $4 \times 7$ & 0.49 & 0.73 & 0.61 & 0.04 & 0.04 & 0.04 & 0.08 & 0.07 & 0.07 \\
\hline $4 \times 8$ & 0.83 & 1.27 & 1.05 & 0.06 & 0.07 & 0.06 & 0.01 & 0.08 & 0.04 \\
\hline $4 \times 9$ & 0.64 & 1.03 & 0.83 & 0.29 & 0.48 & 0.38 & 0.02 & 0.14 & 0.08 \\
\hline $5 \times 6$ & 1.40 & 1.92 & 1.66 & 0.09 & 0.09 & 0.09 & 0.12 & 0.50 & 0.31 \\
\hline $5 \times 7$ & 0.72 & 1.09 & 0.90 & 0.06 & 0.05 & 0.05 & 0.05 & 0.15 & 0.10 \\
\hline $5 \times 8$ & 1.08 & 2.03 & 1.55 & 0.13 & 0.14 & 0.13 & 0.07 & 0.31 & 0.19 \\
\hline $5 \times 9$ & 0.88 & 1.51 & 1.19 & 0.37 & 0.37 & 0.37 & 0.04 & 0.28 & 0.16 \\
\hline $6 \times 7$ & 1.06 & 1.47 & 1.26 & 0.04 & 0.13 & 0.08 & 0.09 & 0.23 & 0.16 \\
\hline $6 \times 8$ & 1.05 & 1.68 & 1.36 & 0.06 & 0.06 & 0.06 & 0.09 & 0.37 & 0.23 \\
\hline $6 \times 9$ & 1.23 & 1.86 & 1.54 & 0.29 & 0.42 & 0.35 & 0.05 & 0.58 & 0.31 \\
\hline $7 \times 8$ & 0.73 & 1.02 & 0.87 & 0.03 & 0.02 & 0.02 & 0.03 & 0.11 & 0.07 \\
\hline $7 \times 9$ & 0.79 & 1.01 & 0.90 & 0.16 & 0.09 & 0.12 & 0.06 & 0.10 & 0.08 \\
\hline $8 \times 9$ & 1.14 & 1.92 & 1.53 & 0.23 & 0.61 & 0.42 & 0.06 & 0.51 & 0.28 \\
\hline Mean & 0.78 & 1.12 & 0.95 & 0.09 & 0.13 & 0.11 & 0.05 & 0.20 & 0.12 \\
\hline LSD (0.05) & 0.27 & 0.30 & & 0.07 & 0.13 & & 0.05 & 0.13 & \\
\hline SE & 0.02 & 0.03 & & 0.008 & 0.01 & & 0.004 & 0.01 & \\
\hline
\end{tabular}

*(1);Ofis 96, (2); TMO 1, (3);Huseyinbey, (4);Celikoglu, (5);Ofis NM, (6);Ofis 1, (7);Bolvadin 95, (8);Ofis 2, (9);TMO T, SE; Standard error

\subsection{Oripavine ratio}

The proportion of oripavine in the parents was found between $0.001 \%$ and $0.073 \%$, and average was $0.010 \%$ in the first year. In the second year the ratio was determined between $0.000 \%$ and $0.178 \%$, and with average of $0.036 \%$. The ratio of oripavine in parents was the highest in TMO T, and the lowest was in Ofis 2. The rate of oripavine in F1 hybrid combinations was determined as $0.001-0.044 \%$, and with average of $0.008 \%$ in the first year, in the second year $0.000-0.118 \%$, and with average of $0.009 \%$.

The cross Ofis NM x TMO T and Bolvadin 95 x TMO T showed the highest oripavine and the lowest was in Ofis $96 \mathrm{x}$ Bolvadin 95 (Table 3 and 5). Yazici et al. (2017) reported that the rate of oripavine ranged between $0.000 \%$ and $0.005 \%$. Yazici \& Yilmaz (2017), reported that the rate of oripavine varied from $0.01 \%$ to $0.02 \%$, in the cultivated as summer and in cultivated as winter; the rate of oripavine varied from $0.0002 \%$ to $0.007 \%$.

\subsection{Papaverine ratio}

The ratio of papaverine in the parents was found between $0.00 \%$ and $0.04 \%$, and average was $0.01 \%$ in the first year and in the second year was determined between $0.00 \%$ and $0.08 \%$ and $0.02 \%$ on average. The highest proportion of papaverine in parents 
was found in Ofis NM, and the lowest was in Celikoglu. The ratio of papaverine in F1 hybrid combinations ranged between 0.00 and $0.08 \%$, and average was $0.02 \%$, in the first year, in the second year ranged between 0.00 and $0.12 \%$, and $0.03 \%$ on the average. The highest ratio of papaverine in hybrids was in Huseyinbey x Ofis 1 and Ofis NM x Ofis 2 hybrid combinations and the lowest was in TMO 1 x Ofis NM (Table 3 and 5). Karabuk (2012) the rate of papaverine between 0.00 and $0.02 \%$, Yazici et al. (2017) the rate of papaverine was reported to be $0.01-0.09 \%$ in varieties and in genotypes was reported to be $0.00-$ $0.21 \%$. Khanna \& Shukla (1991) found a relationship between white latex and papaverine content.

Table 5- Mean values of 2016 and 2017 regarding codeine, oripavine and papaverine ratios in F1 hybrid combinations (\%)

\begin{tabular}{|c|c|c|c|c|c|c|c|c|c|}
\hline \multirow[t]{2}{*}{ *Crosses } & \multicolumn{3}{|c|}{ Codeine (\%) } & \multicolumn{3}{|c|}{ Oripavine (\%) } & \multicolumn{3}{|c|}{ Papaverine (\%) } \\
\hline & 2016 & 2017 & Mean & 2016 & 2017 & Mean & 2016 & 2017 & Mean \\
\hline $1 \times 2$ & 0.04 & 0.09 & 0.06 & 0.003 & 0.017 & 0.010 & 0.00 & 0.01 & 0.00 \\
\hline $1 \times 3$ & 0.06 & 0.06 & 0.06 & 0.002 & 0.000 & 0.001 & 0.01 & 0.03 & 0.02 \\
\hline $1 \times 4$ & 0.04 & 0.05 & 0.04 & 0.003 & 0.000 & 0.001 & 0.01 & 0.00 & 0.00 \\
\hline $1 \times 5$ & 0.07 & 0.09 & 0.08 & 0.004 & 0.000 & 0.002 & 0.02 & 0.02 & 0.02 \\
\hline $1 \times 6$ & 0.05 & 0.16 & 0.10 & 0.003 & 0.012 & 0.007 & 0.01 & 0.00 & 0.00 \\
\hline $1 \times 7$ & 0.05 & 0.08 & 0.06 & 0.001 & 0.000 & 0.000 & 0.00 & 0.01 & 0.00 \\
\hline $1 \times 8$ & 0.03 & 0.04 & 0.03 & 0.002 & 0.000 & 0.001 & 0.00 & 0.01 & 0.00 \\
\hline $1 \times 9$ & 0.03 & 0.11 & 0.07 & 0.012 & 0.000 & 0.006 & 0.01 & 0.06 & 0.03 \\
\hline $2 \times 3$ & 0.04 & 0.07 & 0.05 & 0.002 & 0.042 & 0.022 & 0.03 & 0.02 & 0.02 \\
\hline $2 \times 4$ & 0.05 & 0.08 & 0.06 & 0.002 & 0.000 & 0.001 & 0.00 & 0.02 & 0.01 \\
\hline $2 \times 5$ & 0.04 & 0.08 & 0.06 & 0.001 & 0.003 & 0.002 & 0.00 & 0.05 & 0.02 \\
\hline $2 \times 6$ & 0.04 & 0.13 & 0.08 & 0.003 & 0.008 & 0.005 & 0.00 & 0.00 & 0.00 \\
\hline $2 \times 7$ & 0.05 & 0.10 & 0.07 & 0.003 & 0.004 & 0.003 & 0.01 & 0.02 & 0.01 \\
\hline $2 \times 8$ & 0.04 & 0.09 & 0.06 & 0.002 & 0.000 & 0.001 & 0.00 & 0.06 & 0.03 \\
\hline $2 \times 9$ & 0.07 & 0.08 & 0.07 & 0.003 & 0.007 & 0.005 & 0.01 & 0.00 & 0.00 \\
\hline $3 \times 4$ & 0.05 & 0.14 & 0.09 & 0.002 & 0.000 & 0.001 & 0.03 & 0.05 & 0.04 \\
\hline $3 \times 5$ & 0.04 & 0.11 & 0.07 & 0.008 & 0.007 & 0.007 & 0.06 & 0.09 & 0.07 \\
\hline $3 \times 6$ & 0.08 & 0.13 & 0.10 & 0.002 & 0.000 & 0.001 & 0.08 & 0.11 & 0.09 \\
\hline $3 \times 7$ & 0.05 & 0.09 & 0.07 & 0.002 & 0.000 & 0.001 & 0.03 & 0.04 & 0.03 \\
\hline $3 \times 8$ & 0.04 & 0.01 & 0.02 & 0.002 & 0.029 & 0.015 & 0.02 & 0.00 & 0.01 \\
\hline $3 \times 9$ & 0.11 & 0.14 & 0.12 & 0.014 & 0.009 & 0.011 & 0.05 & 0.07 & 0.06 \\
\hline $4 \times 5$ & 0.07 & 0.07 & 0.07 & 0.021 & 0.000 & 0.010 & 0.00 & 0.03 & 0.01 \\
\hline $4 \times 6$ & 0.11 & 0.17 & 0.14 & 0.006 & 0.000 & 0.003 & 0.02 & 0.06 & 0.04 \\
\hline $4 \times 7$ & 0.06 & 0.10 & 0.08 & 0.004 & 0.012 & 0.008 & 0.01 & 0.02 & 0.01 \\
\hline $4 \times 8$ & 0.05 & 0.07 & 0.06 & 0.002 & 0.000 & 0.001 & 0.01 & 0.00 & 0.00 \\
\hline $4 \times 9$ & 0.11 & 0.09 & 0.10 & 0.021 & 0.000 & 0.010 & 0.02 & 0.00 & 0.01 \\
\hline $5 \times 6$ & 0.08 & 0.17 & 0.12 & 0.002 & 0.026 & 0.014 & 0.07 & 0.05 & 0.06 \\
\hline $5 \times 7$ & 0.07 & 0.07 & 0.07 & 0.006 & 0.000 & 0.003 & 0.01 & 0.03 & 0.02 \\
\hline $5 \times 8$ & 0.07 & 0.13 & 0.10 & 0.010 & 0.000 & 0.005 & 0.06 & 0.12 & 0.09 \\
\hline $5 \times 9$ & 0.14 & 0.12 & 0.13 & 0.044 & 0.118 & 0.081 & 0.00 & 0.10 & 0.05 \\
\hline $6 \times 7$ & 0.06 & 0.12 & 0.09 & 0.003 & 0.000 & 0.001 & 0.02 & 0.02 & 0.02 \\
\hline $6 \times 8$ & 0.05 & 0.03 & 0.04 & 0.004 & 0.000 & 0.002 & 0.01 & 0.02 & 0.01 \\
\hline $6 \times 9$ & 0.12 & 0.21 & 0.16 & 0.029 & 0.000 & 0.014 & 0.02 & 0.00 & 0.01 \\
\hline $7 \mathrm{x} 8$ & 0.02 & 0.05 & 0.03 & 0.002 & 0.009 & 0.005 & 0.01 & 0.00 & 0.00 \\
\hline $7 \times 9$ & 0.09 & 0.07 & 0.08 & 0.026 & 0.073 & 0.049 & 0.00 & 0.01 & 0.00 \\
\hline $8 \times 9$ & 0.09 & 0.14 & 0.11 & 0.033 & 0.000 & 0.016 & 0.01 & 0.00 & 0.00 \\
\hline Mean & 0.06 & 0.10 & 0.08 & 0.008 & 0.010 & 0.009 & 0.02 & 0.03 & 0.02 \\
\hline LSD (0.05) & 0.03 & 0.05 & & 0.01 & 0.03 & & 0.01 & 0.05 & \\
\hline SE & 0.003 & 0.005 & & 0.001 & 0.003 & & 0.002 & 0.004 & \\
\hline
\end{tabular}

*(1); Ofis 96, (2); TMO 1, (3);Huseyinbey, (4); Celikoglu, (5); Ofis NM, (6); Ofis 1, (7); Bolvadin 95, (8); Ofis 2, (9); TMO T, SE; Standard error

\section{Conclusions}

In this study, were used nine parents and 36 hybrid combinations. The experiment was conducted in 2016 and 2017, alkaloid ratios were examined and appropriate parents and hybrid combinations were determined according to alkaloid ratios. According to the average findings of the two years, the parents Ofis 1, Ofis 2, Ofis NM and TMO T were identified as the highest cultivars in a result of investigated all traits. Therefore they could be considered as promising parents in further breeding studies. The mean performance of F1 hybrids was found higher than either of the parental for all traits exhibiting the role of hybrid vigour. In this study, 15 hybrid combinations were found to be higher than the hybrid average values of two years for morphine content and 13 for thebaine, 13 for noscapine, 12 for codeine, 6 for oripavine, 12 for papaverine. Particularly, the crosses Ofis NM x Ofis 1, Ofis 1 x TMO T, Ofis 2 x TMO T, Ofis NM x Ofis 1, Ofis NM x TMO T were 
identified as superior hybrids compared to the others. Hybrid combinations with high alkaloid ratios can be evaluated as suitable hybrids for breeding studies.

\section{Acknowledgements}

This work was supported by the General Directorate of Agricultural Research and Policies (Project numbers: TAGEM/TBAD/16/A04/P06/10).

\section{References}

Arslan N, Buyukgocmen R \& Gumuscu A (2000). Oil and morphine contents of Turkish poppy populations. Journal of Field Crops Central Research Institute 9: 1-2

Baser K H C \& Arslan N (2014). Medicinal and aromatic plants of the middle-east. Opium Poppy (Papaver somniferum L.) Springer Dordrecht Heidelberg, New York London

Bohm H (1981). Papaver bracteatum L. Results and problems of the research on a potential medicinal plant. Pharmazie 36: 660-667

Celik I (2011). Development of SSR markers in poppy (Papaver somniferum L.). Master of Science İn Molecular Biology and Genetics. Izmir Institute of Technology İzmir

Danos B (1968). Retegkromatografias modszer a Papaver somniferum L. Alkaloid spektrumanak nyomon-kiivetesere II. Herba Hungarica, 7(1): 27-37

Dubedout M (1993). Analysis of progenies from a circular plan of crosses in poppy (Papaver somniferum L.). PhD thesis, University of Paris, (Published), Orsay p. 101

Guner A, Aslan S, Ekim T, Vural M \& Babac M T (2012). Turkey Plant List (Vascular Plants). Nezahat Gokyigit Botanical Garden and Flora Research Association Publication. ISBN 978-605-60425-7-7, İstanbul

Harvest T, Brown P H, Fist A, Gracie A, Gregory D \& Koutoulis A (2009). The latex capacity of opium poppy capsules is fixed early in capsule development and is not a major determinant in morphine yield. Annual Applied Biology 154: 251-258

Inal B (2015). Transcriptome based analysis of the thebaine biosynthesis mechanism in opium poppy (Papaver somniferum L.) via next gereation sequencing. PhD thesis, Ankara University, Institute of Biotechnology. Basic Biotechnology, (Published), Ankara

INCB (2020). INCB Narcotic Drugs, Estimated World Requirements for 2020 Statistics for 2018. United Nations Publication, Vienna, 2020, ISBN: 978-92-1-148334-5, e-ISBN: 978-92-1-047695-9

Kara N (2017). The effects of autumn and spring sowing on yield, oil and morphine contents in the turkish poppy (Papaver somniferum L.) cultivars Turk J. Field Crops 2017, 22(1): 39-46, DOI: 10.17557/tjfc.301829

Karabuk B (2012). The effects of nitrogen fertilization and sowing methods on agricultural and quality of poppy (Papaver somniferum L.) variates. PhD thesis, Ondokuz Mayıs University, Graduate School of Natural and Applied Sciences, Department of Field Crops, (Published), Samsun

Khanna K R \& Shukla S (1989). Gene action in opium poppy (Papaver somniferum). The Indian Journal of Agricultural Sciences 59(2):124126

Khanna K R \& Shukla S (1991). Studies on inheritance of papaverine in Papaver somniferum L. and morphological marker for plants with high papaverine content. Herba-Hungarica 30: 7-10

Kucuk Y N (1996). Extraction of alkaloids from the poppy plants grown in different degions of Turkey and investigation of the properties of these compounds in non-aqueous media. PhD thesis, Ankara University, Graduate School of Natural and Applied Sciences Department of Chemistry Supervisor, (Published), Ankara

Laughlin J C (1980). The effect of time of harvest on the yield components of poppies (Papaver somniferum L.) Journal of Agricultural Sciences, Cambridge 95: 667-676

Levy A, Milo J \& Palevitch D (1988). Accumulation and distribution of thebaine in the roots of Papaver bracteatum during plant development. Planta Medica 54: 299-301

Levy A, Palevitch D, Milo J \& Lavie D (1986). Effect of gibberellic acid on flowering and the thebaine yield of different clones of Papaver bracteatum. Plant Growth Regul 4: 153-157

Marciano M A, Panicker S X, Liddil G D, Lindgren D \& Sweder K S (2018). Development of a method to extract opium poppy (Papaver somniferum L.) DNA from heroin. Scientific reports, 2590./10.1038/s41598-018-20996-9

Mishra B K, Rastogi A, Siddiqui A, Srivastava M, Verma N, Pandey R, Sharma N C \& Shukla S (2013). Opium poppy: Genetic upgradation through intervention of plant breeding techniques. 10.5772/53132

Ozgen Y, Arslan N \& Bayraktar N (2017). Comparison of yield and alkaloid ratios of poppy (Papaver somniferum L.) lines in the F3 level. $12^{\text {th }}$ Field Crops Congress, Electronic Congress Book, 12-15 September, Kahramanmaras, Turkey pp. 146

Saco M D \& Lopez-Belmonte F (1988). Influence of climatic condition on the Papaver bracteatum thebaine content. Fitoterapia, 6: 488-493

Tan A O (2008). Food and Morality: The Poppy, Potent yet Frail, Proceedings of the Oxford Symposium on Food and Cookery 2007, Devon, Prospects Books, 20 Aug 2008 pp. 279-287

Tanker M \& Tanker N (1990). Pharmacognosy Volume II. Ankara University, Faculty of Pharmacy, Publications No, 65. Ankara

TMO (2014). 2013 Poppy Sector Report. Turkish Grain Board General Directorate, Ankara

TMO (2017). 2016 Poppy Report. Turkish Grain Board General Directorate, Ankara

UNODC (2018). The Opium alkaloids. United Nations Office on Drugs and Crime Pages, 13 to 14 https://www.unodc.org/unodc/en/dataand-analysis/bulletin

Yadav H K, Shukla S, Rastogi A \& Singh S P (2007). Assessment of diversity in new genetic stock of opium poppy (Papaver somniferum L.). The Indian Journal of Agricultural Sciences 77: 537-539

Yazici L \& Y1lmaz G (2017). Determination of alkaloids and oil rates of some poppy (Papaver somniferum L.) varieties cultivated as winter and summer. Int. J. Sec. Metabolite 4 (3): 359-362

Yazici L, Yilmaz G \& Gokalp S (2017). Determination of Alkaloids and Oil Rates of Some Poppy (Papaver somniferum L.) Varieties and Genotypes. Research Article, Kahramanmaras Sutcu Imam University, Journal of Natural Sciences, 20 (Special Issue) pp. 313-317 